\title{
Paenibacillus assamensis sp. nov., a novel bacterium isolated from a warm spring in Assam, India
}

Correspondence

T. Chakrabarti

tapan@imtech.res.in

\author{
P. Saha, ${ }^{1,2}$ A. K. Mondal, ${ }^{2}$ S. Mayilraj, ${ }^{1,2}$ S. Krishnamurthi, ${ }^{1,2}$ \\ A. Bhattacharya ${ }^{1,2}$ and T. Chakrabarti, ${ }^{1,2}$ \\ Microbial Type Culture Collection and Gene Bank (MTCC) ${ }^{1}$ and Institute of Microbial \\ Technology², Sector 39A, Chandigarh 160 036, India
}

The genus Bacillus was created by Cohn in 1872 and accommodates Gram-positive, aerobic or facultatively anaerobic, endospore-forming rods (Claus \& Berkeley, 1986). On the basis of $16 \mathrm{~S}$ rRNA-based molecular analysis it became apparent that the genus is very heterogeneous, consisting of different phylogenetic groups (Ash et al., 1991). Later, Ash et al. (1993) moved the members of Bacillus group 3 to the genus Paenibacillus. Thereafter, its description was emended by Shida et al. (1997). At present, more than 60 species (http://www.bacterio.cict.fr/p/ paenibacillus.html) are recognized as members of the genus Paenibacillus. Members of this genus produce ellipsoidal endospores in swollen sporangia, possess $C_{15: 0}$ anteiso as the major cellular fatty acid and have genomic DNA G + C contents in the range 39-54 mol\% (Shida et al., 1997; Montes et al., 2004; Takeda et al., 2005). Species belonging

Published online ahead of print on 16 September 2005 as DOI 10.1099/ijs.0.63846-0.

The GenBank/EMBL/DDBJ accession number for the 16S rRNA gene sequence of Paenibacillus assamensis GPTSA $11^{\top}$ is AY884046. to the genus Paenibacillus have been isolated from various ecological niches such as soil, rhizospheres, water, diseased insect larvae, food (Daane et al., 2002), cow faeces (Velázquez et al., 2004), blood cultures (Roux \& Raoult, 2004), Antarctic sediment (Montes et al., 2004) and recently from the phyllosphere of Phoenix dactylifera (Rivas et al., 2005). Examination of such habitats has resulted in the discovery of 23 novel species in the last 3 years (2002-2004).

In this paper, we report the taxonomic characterization of a novel aerobic, mesophilic, Gram-variable, endosporeforming bacterial strain, GPTSA $11^{\mathrm{T}}$, which produces spreading colonies. Strain GPTSA $11^{\mathrm{T}}$ was isolated from a warm-spring water sample by dilution-plating on tryptic soy broth agar (TSBA; tryptic soy broth, $3 \%$; agar, $1.5 \%$ ). The warm spring is located in a reserve forest inhabited by wild elephants and other animals and is rarely disturbed by human activities. As elephant dung was found in and around the spring, it can be assumed that this is a water hole used by animals living in the forest. The temperature of the spring was $38^{\circ} \mathrm{C}$ and the $\mathrm{pH}$ was $7 \cdot 2$. The colony 
morphology, cell morphology, motility and Gram reaction of the strain were determined by using standard methods (Smibert \& Krieg, 1994; Murray et al., 1994; Powers, 1995). Physiological characteristics were examined by growing the isolate on basal TSBA medium at different temperatures, $\mathrm{pH}$ values and $\mathrm{NaCl}$ concentrations. After $36 \mathrm{~h}$ growth at $30^{\circ} \mathrm{C}$ on TSBA, colonies were round and yellowish white in colour. Within $48 \mathrm{~h}$, the entire plate was occupied by single colonies apparently produced as a result of 'jumping' from the primary inoculum. The isolate was able to grow at temperatures between 20 and $37^{\circ} \mathrm{C}$, at $\mathrm{pH} 6 \cdot 8-12 \cdot 0$ and was able to tolerate $\mathrm{NaCl}$ concentrations of up to $2.5 \%$. Various biochemical tests were done at $30{ }^{\circ} \mathrm{C}$ using standard methods (Claus \& Berkeley, 1986; Smibert \& Krieg, 1994). Degradation of chitin and xylan was checked on nutrient agar (HiMedia) medium supplemented with $0.4 \%(\mathrm{w} / \mathrm{v})$ each compound. Acid production from various carbohydrates were checked on basal medium (beef extract, $0 \cdot 3 \%$; tryptose, $1 \% ; \mathrm{NaCl}, 0.5 \%$; phenol red as acid-base indicator) supplemented with $0.5 \%$ carbohydrate. The biochemical and physiological characteristics of the strain are given in the species description.

For cellular fatty acid analysis, the strain was grown on TSBA medium at $30^{\circ} \mathrm{C}$ for $24 \mathrm{~h}$. Extraction and analysis of cellular fatty acids were done using the Sherlock Microbial Identification System (MIDI), as described previously (Pandey et al., 2002). The major fatty acid was found to be $\mathrm{C}_{15: 0}$ anteiso, followed by $\mathrm{C}_{16: 0}$ iso, $\mathrm{C}_{16: 1} \omega 11 c, \mathrm{C}_{15: 0}$ iso, $\mathrm{C}_{17: 0}$ anteiso and $\mathrm{C}_{16: 1} \omega 7 c$ alcohol (Table 1). The diagnostic cell-wall amino acid was found to be mesodiaminopimelic acid, as determined by TLC (Staneck \& Roberts, 1974). Menaquinones were extracted from $200 \mathrm{mg}$ dry cell mass with a $10 \%$ aqueous solution of $0.3 \%(\mathrm{w} / \mathrm{v})$ $\mathrm{NaCl}$ in methanol and petroleum ether $\left(60-80^{\circ} \mathrm{C}\right.$ boiling point) at a ratio of $1: 1$. The upper phase was collected and dried in a Turbo Vap LV evaporator (Zymark). The residue was dissolved in $100 \mu$ l acetone. The extract was developed on a TLC plate $\left(20 \times 20 \mathrm{~cm}\right.$ Silica gel $60 \mathrm{~F}_{254}$; Merck $)$ using petroleum ether (boiling point $60-80{ }^{\circ} \mathrm{C}$ ) and diethyl ether $(85: 15, \mathrm{v} / \mathrm{v})$. Purified menaquinones were dissolved in 2propanol and analysed by reverse-phase TLC according to Collins \& Jones (1980). The diagnostic menaquinone of strain GPTSA $11^{\mathrm{T}}$ was found to be MK-7. The genomic DNA of GPTSA $11^{\mathrm{T}}$ was isolated by using Marmur's protocol (Johnson, 1994). The G $+\mathrm{C}$ content of the genomic DNA was determined spectrophotometrically (Lambda $35 \mathrm{spec}-$ trophotometer; Perkin Elmer), using the thermal denaturation method (Mandel \& Marmur, 1968), and was found to be $41 \cdot 2 \mathrm{~mol} \%$. A fragment comprising the full-length $16 \mathrm{~S}$ rRNA gene from strain GPTSA $11^{\mathrm{T}}$ was amplified by a PCR using primers 8-27f (5'-AGAGTTTGATCCTGGCTCAG$\left.3^{\prime}\right)$ and 1500r (5'-AGAAAGGAGGTGATCCAGGC-3') (Escherichia coli numbering). The amplification reaction and the purification of amplicons were performed as described previously (Pandey et al., 2002). The purified PCR product was sequenced by using the dideoxy chain terminator method with the Big Dye Terminator kit
Table 1. Cellular fatty acid composition of strain GPTSA $11^{\top}$ and phylogenetically related Paenibacillus species

Values are percentages of total fatty acids. Species/strains: 1, GPTSA $11^{\mathrm{T}} ; 2$, P. apiarius MTCC $1497^{\mathrm{T}}$ (data from this study); 3, P. alvei (data from Shida et al., 1997); 4, P. cineris (Logan et al., 2004); 5, P. favisporus (Velázquez et al., 2004); 6, P. thiaminolyticus (Shida et al., 1997); 7, P. popilliae (Pettersson et al., 1999; only major fatty acid data were available); 8, Paenibacillus polymyxa (Yoon et al., 2003). Summed feature 4 comprises $\mathrm{C}_{17: 1}$ iso I and/or $\mathrm{C}_{17: 1}$ anteiso B. ND, Not detected; NM, not mentioned.

\begin{tabular}{|lcccccccc|}
\hline Fatty acid & $\mathbf{1}$ & $\mathbf{2}$ & $\mathbf{3}$ & $\mathbf{4}$ & $\mathbf{5}$ & $\mathbf{6}$ & $\mathbf{7}$ & $\mathbf{8}$ \\
\hline $\mathrm{C}_{10: 0}$ & $0 \cdot 64$ & $\mathrm{ND}$ & $\mathrm{NM}$ & $\mathrm{NM}$ & $\mathrm{NM}$ & $\mathrm{NM}$ & $\mathrm{NM}$ & $\mathrm{NM}$ \\
$\mathrm{C}_{11: 0} 2-\mathrm{OH}$ & $\mathrm{ND}$ & $\mathrm{ND}$ & $\mathrm{NM}$ & $\mathrm{NM}$ & $\mathrm{NM}$ & $\mathrm{NM}$ & $\mathrm{NM}$ & $0 \cdot 8$ \\
$\mathrm{C}_{14: 0}$ & $1 \cdot 80$ & $1 \cdot 15$ & $2 \cdot 3$ & $2 \cdot 96$ & $1 \cdot 2$ & $0 \cdot 9$ & $\mathrm{NM}$ & $0 \cdot 7$ \\
$\mathrm{C}_{15: 0}$ & $\mathrm{ND}$ & $\mathrm{ND}$ & $1 \cdot 6$ & $1 \cdot 93$ & $3 \cdot 6$ & $0 \cdot 6$ & $6 \cdot 8$ & $0 \cdot 5$ \\
$\mathrm{C}_{16: 0}$ & $3 \cdot 49$ & $5 \cdot 9$ & $15 \cdot 3$ & $18 \cdot 73$ & $8 \cdot 7$ & $10 \cdot 5$ & 31 & $9 \cdot 1$ \\
$\mathrm{C}_{17: 0}$ & $1 \cdot 56$ & $1 \cdot 25$ & $\mathrm{NM}$ & $\mathrm{NM}$ & $\mathrm{NM}$ & $\mathrm{NM}$ & $\mathrm{NM}$ & $\mathrm{ND}$ \\
$\mathrm{C}_{18: 0}$ & $\mathrm{ND}$ & $\mathrm{ND}$ & $\mathrm{NM}$ & $\mathrm{NM}$ & $\mathrm{NM}$ & $\mathrm{NM}$ & $\mathrm{NM}$ & $1 \cdot 1$ \\
$\mathrm{C}_{14: 0}$ iso & $4 \cdot 74$ & $0 \cdot 97$ & $0 \cdot 3$ & $1 \cdot 19$ & $0 \cdot 9$ & $0 \cdot 6$ & $\mathrm{NM}$ & $0 \cdot 6$ \\
$\mathrm{C}_{15: 0}$ anteiso & $48 \cdot 42$ & $49 \cdot 96$ & $53 \cdot 9$ & $43 \cdot 15$ & $48 \cdot 8$ & $42 \cdot 4$ & 32 & $49 \cdot 9$ \\
$\mathrm{C}_{15: 0}$ iso & $6 \cdot 03$ & $13 \cdot 55$ & $12 \cdot 3$ & $6 \cdot 25$ & $6 \cdot 5$ & $10 \cdot 5$ & $3 \cdot 2$ & $5 \cdot 5$ \\
$\mathrm{C}_{16: 0}$ iso & $11 \cdot 59$ & $6 \cdot 52$ & $2 \cdot 3$ & $9 \cdot 09$ & $11 \cdot 1$ & $5 \cdot 8$ & $\mathrm{NM}$ & $7 \cdot 7$ \\
$\mathrm{C}_{17: 0}$ anteiso & $5 \cdot 68$ & $8 \cdot 80$ & $3 \cdot 3$ & $10 \cdot 72$ & $15 \cdot 0$ & $11 \cdot 6$ & $\mathrm{NM}$ & $16 \cdot 7$ \\
$\mathrm{C}_{17: 0}$ iso & $1 \cdot 59$ & $6 \cdot 39$ & $3 \cdot 3$ & $2 \cdot 99$ & $\mathrm{NM}$ & $6 \cdot 5$ & $\mathrm{NM}$ & $7 \cdot 0$ \\
$\mathrm{C}_{16: 1} \omega 11 c$ & $6 \cdot 16$ & $2 \cdot 18$ & $1 \cdot 3^{*}$ & $\mathrm{NM}$ & $\mathrm{NM}$ & $5 \cdot 2^{*}$ & $\mathrm{NM}$ & $\mathrm{ND}$ \\
$\mathrm{C}_{16: 1} \omega 7 c$ alcohol & $5 \cdot 01$ & $\mathrm{ND}$ & $\mathrm{NM}$ & $\mathrm{NM}$ & $\mathrm{NM}$ & $\mathrm{NM}$ & $\mathrm{NM}$ & $\mathrm{NM}$ \\
$\mathrm{C}_{17: 1} \omega 10 c$ iso & $1 \cdot 18$ & $1 \cdot 35$ & $0 \cdot 5 *$ & $\mathrm{NM}$ & $\mathrm{NM}$ & $1 \cdot 7 *$ & $\mathrm{NM}$ & $\mathrm{NM}$ \\
$\mathrm{C}_{17: 1} \omega 6 c$ & $\mathrm{ND}$ & $\mathrm{ND}$ & $\mathrm{NM}$ & $\mathrm{NM}$ & $\mathrm{NM}$ & $\mathrm{NM}$ & $\mathrm{NM}$ & $0 \cdot 7$ \\
Summed feature & $1 \cdot 64$ & $0 \cdot 92$ & $\mathrm{NM}$ & $\mathrm{NM}$ & $\mathrm{NM}$ & $\mathrm{NM}$ & $\mathrm{NM}$ & $\mathrm{ND}$ \\
& & & & & & & & \\
\hline
\end{tabular}

${ }^{*}$ The cis/trans isomeric nature of the fatty acids was not specified; rather, these were reported as $\mathrm{C}_{16: 1} \omega 11$ and $\mathrm{C}_{17: 1} \omega 10$ iso, respectively.

followed by capillary electrophoresis on an ABI 310 Genetic Analyzer (Applied Biosystems). An almost-complete (1466 nt continuous stretch) 16S rRNA gene sequence of the strain was used as a query to search for homologous sequences in the GenBank database and in the Ribosomal Database Project library (Project II, release 9; http://rdp.cme.msu.edu/index. jsp). Analysis of the sequence indicated that GPTSA $11^{\mathrm{T}}$ contains the consensus signature sequence stretches PAEN 515F (5'-GAGTAACTGCTCTCGGAATGACGGTACTTGAGAAGAAAGCCCC-3') (Shida et al., 1997) and PAEN 862F (5'-TCGATACCCTTGGTGCCGAAGT-3') (Pettersson et al., 1999), which are mostly found among different species within the genus Paenibacillus. Strain GPTSA $11^{\mathrm{T}}$ showed the highest degree of sequence similarity with Paenibacillus apiarius DSM $5581^{\mathrm{T}}(95 \cdot 85 \%)$, followed by Paenibacillus alvei IAM $1258^{\mathrm{T}}$ (94.34\%), Paenibacillus cineris LMG $18439^{\mathrm{T}}(93 \cdot 87 \%)$, Paenibacillus favisporus GMP $01^{\mathrm{T}}(93 \cdot 80 \%)$, Paenibacillus chibensis JCM $11200^{\mathrm{T}}(93 \cdot 47 \%)$ and Paenibacillus azoreducens $\mathrm{CM}^{\mathrm{T}}(93 \cdot 40 \%)$. Sequences from type strains of these six and 13 other species of Paenibacillus showing more than $92 \cdot 50 \%$ similarity were used for phylogenetic analysis. These sequences 
were aligned with that of strain GPTSA $11^{\mathrm{T}}$ by the CLUSTAL $\mathrm{X}$ program (Thompson et al., 1997) and edited manually. Aligned sequences were analysed by the PHYLIP software package, version 3.5c (Felsenstein, 1993). Computation of pairwise evolutionary distances for the aligned sequences was done using the DNADIST program with the Kimura twoparameter model (Kimura, 1980). To obtain the confidence value for the aligned sequence dataset, bootstrap analysis of 100 replications were done using SEQBOOT. Phylogenetic trees showing the relationships between GPTSA $11^{\mathrm{T}}$ and other reference strains were constructed using the neighbourjoining method (Saitou \& Nei, 1987) and the unweighted pair group arithmetic averages linkage algorithm. Distance-matrix data obtained from DNADIST were also used to construct a phylogenetic tree by using KITSCH. Consensus trees for each of these methods were generated using CONSENSE from the PHYLIP package. Irrespective of the different tree-generating methods used, strain GPTSA $11^{\mathrm{T}}$ always occurred as a separate clade within the Paenibacillus thiaminolyticus-Paenibacillus popilliae-P. alvei-P. apiarius cluster (Fig. 1). The 16S rRNA gene sequence similarity of these strains with respect to GPTSA $11^{\mathrm{T}}$ lies between $92 \cdot 98$ and $95 \cdot 85 \%$. The overall genomic relatedness of GPTSA $11^{\mathrm{T}}$ with respect to these species may not be high because, as Stackebrandt \& Goebel (1994) observed, strains with less than $97 \%$ 16S rRNA gene sequence similarity have DNA-DNA relatedness values below $70 \%$. The latter percentage of genomic relatedness is considered as the 'gold standard' for bacterial species definition (Wayne et al., 1987). Thus, in the absence of a close relative with significant 16S rRNA gene sequence similarity, strain GPTSA $11^{\mathrm{T}}$ can be considered as a novel species. The presence of ellipsoidal endospores, $\mathrm{C}_{15: 0}$ anteiso

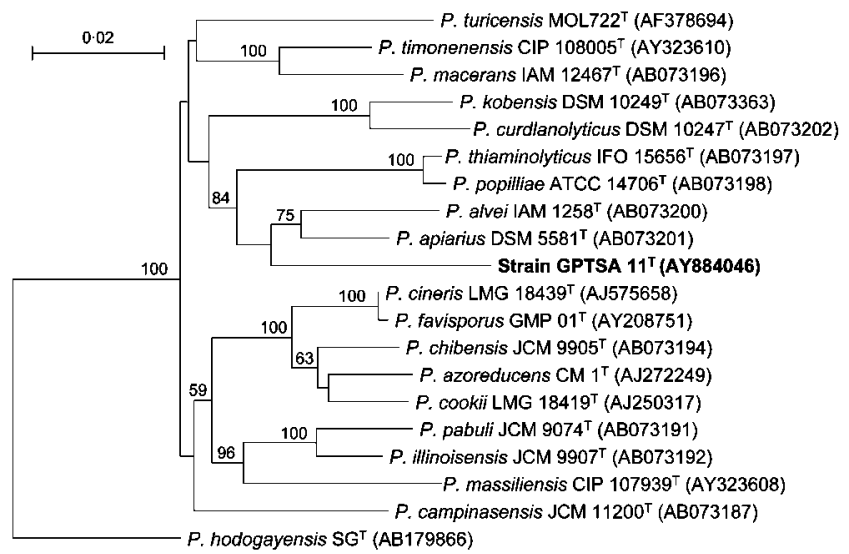

Fig. 1. Phylogenetic relationships of strain GPTSA $11^{\top}$ and other closely related Paenibacillus species based on 16S rRNA gene sequences. The tree was generated using the neighbourjoining method and displayed with TREECON software (Van de Peer \& De Wachter, 1997). Bootstrap values as percentages of 100 replications are shown at branches. The sequence from Paenibacillus hodogayensis $\mathrm{SG}^{\top}$ is taken as the outgroup. Bar, 0.02 substitutions per site. as a major fatty acid, meso-diaminopimelic acid as a cell-wall amino acid, MK-7 as the diagnostic menaquinone and PAEN 515F and PAEN 862F signature sequences in the 16S rRNA gene suggest that the strain belongs to the genus Paenibacillus. However, it differs from closely related species in terms of several phenotypic characteristics and the DNA G $+\mathrm{C}$ content (Table 2). In addition, unlike P. cineris, strain GPTSA $11^{\mathrm{T}}$ cannot produce acid from L-arabinose, myo-inositol, Dmelezitose, arbutin, D-fructose, galactose or lactose. Close phylogenetic relatives also differ from GPTSA $11^{\mathrm{T}}$ in terms of cellular fatty acid composition, both qualitatively and quantitatively (Table 1). On the basis of the phenotypic, chemotaxonomic and phylogenetic data, it is evident that GPTSA $11^{\mathrm{T}}$ represents a novel species within the genus Paenibacillus, for which we propose the name Paenibacillus assamensis sp. nov.

\section{Description of Paenibacillus assamensis sp. nov.}

Paenibacillus assamensis (as.sam.en'sis. N.L. masc. adj. assamensis pertaining to Assam, a north-eastern state in India, where the type strain was isolated).

Gram-variable, strictly aerobic, mesophilic, sporulating, motile rods occurring as single cells or in pairs. Cells measure $1 \cdot 0-2 \cdot 5 \mu \mathrm{m}$ in length and $0 \cdot 5-0.6 \mu \mathrm{m}$ in width. Colonies are round, convex with undulated margins and light yellowish-white in colour, spreading as single colonies over the entire plate. Endospores are ellipsoidal and subterminal, occurring in bulging sporangia. The strain can grow at temperatures between 20 and $37^{\circ} \mathrm{C}$, at $\mathrm{pH}$ values in the range $6 \cdot 8-12 \cdot 0$ and can tolerate $\mathrm{NaCl}$ at concentrations of up to $2.5 \%$. It is oxidase-, catalase-, gelatinaseand arginine dihydrolase-positive but negative for urease, DNase, phenylalanine deaminase, lysine and ornithine decarboxylase activities. Negative for indole and $\mathrm{H}_{2} \mathrm{~S}$ production, nitrate reduction, in the Voges-Proskauer test and for gas production from glucose but gives a positive result in the methyl red test. Cannot utilize acetate, citrate or propionate. Hydrolyses starch, aesculin and casein but not tyrosine, ONPG or Tweens 20, 40 and 80. Produces acid from D-glucose, glycerol, gentiobiose, glycogen, D-maltose, D-mannose, D-ribose, produces acid weakly from Damygdalin, cellobiose, sucrose and trehalose, but not from adonitol, L-arabinose, D-arabinose, L-arabitol, arbutin, D-fructose, D-galactose, myo-inositol, inulin, D-lactose, D-mannitol, D-melibiose, D-melezitose, D-raffinose, Lrhamnose, salicin, sorbitol, L-sorbose, xylitol or D-xylose. Can grow in the presence of $0.001 \%$ lysozyme but not $0.01 \%$ lysozyme. Cannot degrade chitin or xylan. The major fatty acids are $\mathrm{C}_{15: 0}$ anteiso, followed by $\mathrm{C}_{16: 0}$ iso, $\mathrm{C}_{16: 1} \omega 11 c, \mathrm{C}_{15: 0}$ iso, $\mathrm{C}_{17: 0}$ anteiso and $\mathrm{C}_{16: 1} \omega 7 c$ alcohol. The cell-wall amino acid is meso-diaminopimelic acid. The diagnostic menaquinone is MK-7. The DNA G $+\mathrm{C}$ content is $41 \cdot 2 \mathrm{~mol} \%$.

The type strain is GPTSA $11^{\mathrm{T}}\left(=\right.$ MTCC $6934^{\mathrm{T}}=\mathrm{JCM}$ $13186^{\mathrm{T}}$ ), isolated from a warm-spring water sample from Assam, India. 
Table 2. Comparison of phenotypic properties and $G+C$ content of GPTSA $11^{\top}$ and closely related Paenibacillus species

Species/strains: 1, GPTSA $11^{\mathrm{T}}$; 2, P. apiarius MTCC $1497^{\mathrm{T}}$ (data from this study); 3, P. alvei (data from Shida et al., 1997); 4, P. cineris (Logan et al., 2004) 5, P. favisporus (Velázquez et al., 2004). 6, $P$. thiaminolyticus (Shida et al., 1997); 7, P. popilliae (Pettersson et al., 1999); 8, P. polymyxa MTCC $122^{\mathrm{T}}$ (data from this study unless indicated). +, Positive; -, negative; V, variable; W, weak; ND, not determined.

\begin{tabular}{|c|c|c|c|c|c|c|c|c|}
\hline Characteristic & 1 & 2 & 3 & 4 & 5 & 6 & 7 & 8 \\
\hline $\begin{array}{l}\text { Spreading colonial } \\
\text { growth }\end{array}$ & + & - & + & - & - & - & - & - \\
\hline Anaerobic growth & - & + & + & + & + & + & + & + \\
\hline Nitrate reduction & - & + & - & + & + & + & - & + \\
\hline \multicolumn{9}{|l|}{ Production of: } \\
\hline Acetylmethylcarbinol & - & - & + & $\mathrm{v} / \mathrm{w}$ & - & - & - & + \\
\hline Indole & - & - & + & - & - & + & - & - \\
\hline Dihydroxyacetone & - & - & + & $\mathrm{ND}$ & - & - & $\mathrm{ND}$ & + \\
\hline $\begin{array}{l}\text { Decomposition } \\
\text { of tyrosine }\end{array}$ & - & + & $\mathrm{V}$ & ND & - & + & - & - \\
\hline \multicolumn{9}{|l|}{ Hydrolysis of: } \\
\hline Casein & + & + & + & $\mathrm{W}$ & - & + & - & + \\
\hline Urea & - & + & $\mathrm{ND}$ & - & + & - & $\mathrm{ND}$ & - \\
\hline Growth at $\mathrm{pH} 5 \cdot 6$ & - & + & - & + & + & - & - & + \\
\hline Growth in $5 \% \mathrm{NaCl}$ & - & + & $\mathrm{V}$ & - & $\mathrm{W}$ & $\mathrm{V}$ & $\mathrm{ND}$ & - \\
\hline \multicolumn{9}{|l|}{ Acid production from: } \\
\hline Mannitol & - & - & - & + & + & $\mathrm{v}$ & - & + \\
\hline D-Xylose & - & - & - & + & + & - & - & + \\
\hline $\mathrm{G}+\mathrm{C}$ content $(\mathrm{mol} \%)$ & $41 \cdot 2$ & $51 \cdot 3$ & $45-47$ & $51 \cdot 5$ & 53 & $52-54$ & $\mathrm{ND}$ & $43-46^{\star}$ \\
\hline
\end{tabular}

${ }^{\star}$ Data from Shida et al. (1997).

\section{Acknowledgements}

We are grateful to Dr K. Ganesan for his help with DNA sequencing and Dr G. S. Prasad and Dr K. Suresh for their advice and for fruitful discussions. The help of Dr T. C. Bora (Regional Research Laboratory, Jorhat, India) is gratefully acknowledged. We also thank the Editor and referees for making useful suggestions. Financial assistance from DBT, Government of India, and CSIR is duly acknowledged. P. S., S. K. and A. B. are recipients of CSIR fellowships. This is IMTECH communication number 011/2005.

\section{References}

Ash, C., Farrow, J. A. E., Wallbanks, S. \& Collins, M. D. (1991). Phylogenetic heterogeneity of the genus Bacillus revealed by comparative analysis of small subunit ribosomal RNA sequences. Lett Appl Microbiol 13, 202-206.

Ash, C., Priest, F. G. \& Collins, M. D. (1993). Molecular identification of rRNA group 3 bacilli (Ash, Farrow, Wallbanks and Collins) using a PCR probe test. Proposal for the creation of a new genus Paenibacillus. Antonie van Leeuwenhoek 64, 253-260.

Claus, D. \& Berkeley, R. C. W. (1986). Genus Bacillus Cohn 1872, $174^{\mathrm{AL}}$. In Bergey's Manual of Systematic Bacteriology, vol. 2, pp. 1105-1139. Edited by P. H. A. Sneath, N. S. Mair, M. E. Sharpe \& J. G. Holt. Baltimore: Williams \& Wilkins.
Collins, M. D. \& Jones, D. (1980). Lipids in the classification and identification of coryneform bacteria containing peptidoglycan based on 2,4-diamino butyric acid (DAB). J Appl Bacteriol 48, 459-470.

Daane, L. L., Harjono, I., Barns, S. M., Launen, L. A., Palleroni, N. J. \& Häggblom, M. M. (2002). PAH-degradation by Paenibacillus spp. and description of Paenibacillus naphthalenovorans sp. nov., a naphthalenedegrading bacterium from the rhizosphere of salt marsh plants. Int J Syst Evol Microbiol 52, 131-139.

Felsenstein, J. (1993). PHYLIP (phylogeny inference package), version 3.5c. Distributed by the author. Department of Genome Sciences, University of Washington, Seattle, USA.

Johnson, J. L. (1994). Similarity analysis of DNAs. In Methods for General and Molecular Bacteriology, pp. 656-682. Edited by P. Gerhardt, R. G. E. Murray, W. A. Wood \& N. R. Krieg. Washington, DC: American Society for Microbiology.

Kimura, M. (1980). A simple method for estimating evolutionary rates of base substitutions through comparative studies of nucleotide sequences. J Mol Evol 16, 111-120.

Logan, N. A., De Clerck, E., Lebbe, L., Verhelst, A., Goris, J., Forsyth, G., Rodriguez-Diaz, M., Heyndrickx, M. \& De Vos, P. (2004). Paenibacillus cineris sp. nov. and Paenibacillus cookii sp. nov. from Antarctic volcanic soils and a gelatin-processing plant. Int J Syst Evol Microbiol 54, 1071-1076.

Mandel, M. \& Marmur, J. (1968). Use of ultraviolet absorbancetemperature profile for determining the guanine plus cytosine content of DNA. Methods Enzymol 12B, 195-206. 
Montes, J. M., Mercadé, E., Bozal, N. \& Guinea, J. (2004). Paenibacillus antarcticus sp. nov., a novel psychrotolerant organism from the Antarctic environment. Int J Syst Evol Microbiol 54, 1521-1526.

Murray, R. G. E., Doetsch, R. N. \& Robinow, C. F. (1994). Determinative and cytological light microscopy. In Methods for General and Molecular Bacteriology, pp. 21-41. Edited by P. Gerhardt, R. G. E. Murray, W. A. Wood \& N. R. Krieg. Washington, DC: American Society for Microbiology.

Pandey, K. K., Mayilraj, S. \& Chakrabarti, T. (2002). Pseudomonas indica sp. nov., a novel butane-utilizing species. Int J Syst Evol Microbiol 52, 1559-1567.

Pettersson, B., Rippere, K. E., Yousten, A. A. \& Priest, F. G. (1999). Transfer of Bacillus lentimorbus and Bacillus popilliae to the genus Paenibacillus with emended descriptions of Paenibacillus lentimorbus comb. nov. and Paenibacillus popilliae comb. nov. Int J Syst Bacteriol 49, 531-540.

Powers, E. M. (1995). Efficacy of the Ryu nonstaining $\mathrm{KOH}$ technique for rapidly determining gram reactions of food-borne and waterborne bacteria and yeasts. Appl Environ Microbiol 61, 3756-3758.

Rivas, R., Mateos, P. F., Martínez-Molina, E. \& Velázquez, E. (2005). Paenibacillus phyllosphaerae sp. nov., a xylanolytic bacterium isolated from the phyllosphere of Phoenix dactylifera. Int J Syst Evol Microbiol 55, 743-746.

Roux, V. \& Raoult, D. (2004). Paenibacillus massiliensis sp. nov., Paenibacillus sanguinis sp. nov. and Paenibacillus timonensis sp. nov., isolated from blood cultures. Int J Syst Evol Microbiol 54, 1049-1054.

Saitou, N. \& Nei, M. (1987). The neighbor-joining method: a new method for reconstructing phylogenetic trees. Mol Biol Evol 4, 406-425.

Shida, O., Takagi, H., Kadowaki, K., Nakamura, L. K. \& Komagata, K. (1997). Transfer of Bacillus alginolyticus, Bacillus chondroitinus, Bacillus curdlanolyticus, Bacillus glucanolyticus, Bacillus kobensis, and Bacillus thiaminolyticus to the genus Paenibacillus and emended description of the genus Paenibacillus. Int J Syst Bacteriol 47, 289-298.
Smibert, R. M. \& Krieg, N. R. (1994). Phenotypic characterization. In Methods for General and Molecular Bacteriology, pp. 607-654. Edited by P. Gerhardt, R. G. E. Murray, W. A. Wood \& N. R. Krieg. Washington, DC: American Society for Microbiology.

Stackebrandt, E. \& Goebel, B. M. (1994). Taxonomic note: a place for DNA-DNA reassociation and 16S rRNA sequence analysis in the present species definition in bacteriology. Int J Syst Bacteriol 44, 846-849.

Staneck, J. L. \& Roberts, G. D. (1974). Simplified approach to identification of aerobic actinomycetes by thin-layer chromatography. Appl Microbiol 28, 226-231.

Takeda, M., Suzuki, I. \& Koizumi, J. (2005). Paenibacillus hodogayensis sp. nov., capable of degrading the polysaccharide produced by Sphaerotilus natans. Int J Syst Evol Microbiol 55, 737-741.

Thompson, J. D., Gibson, T. J., Plewniak, F., Jeanmougin, F. \& Higgins, D. G. (1997). The CLUSTAL_X Windows interface: flexible strategies for multiple sequence alignment aided by quality analysis tools. Nucleic Acids Res 25, 4876-4882.

Van de Peer, Y. \& De Wachter, R. (1997). Construction of evolutionary distance trees with TREECON for Windows: accounting for variation in nucleotide substitution rate among sites. Comput Appl Biosci 13, 227-230.

Velázquez, E., de Miguel, T., Poza, M., Rivas, R., Rosselló-Mora, R. \& Villa, G. T. (2004). Paenibacillus favisporus sp. nov., a xylanolytic bacterium isolated from cow faeces. Int J Syst Evol Microbiol 54, 59-64.

Wayne, L. G., Brenner, D. J., Colwell, R. R. \& 9 other authors (1987). International Committee on Systematic Bacteriology. Report of the ad hoc committee on reconciliation of approaches to bacterial systematics. Int J Syst Bacteriol 37, 463-464.

Yoon, J.-H., Oh, H.-M., Yoon, B.-D., Kang, K. H. \& Park, Y.-H. (2003). Paenibacillus kribbensis sp. nov. and Paenibacillus terrae sp. nov., bioflocculants for efficient harvesting of algal cells. Int J Syst Evol Microbiol 53, 295-301. 